\title{
Bitter Scrolls: Sexist Poison in the Canon, by Pe- ter Heinegg
}

Washington, D.C.: University Press of America, 2010 | I72 pages | ISBN: 978-0-76I-85288-9 (softback) \$26.50

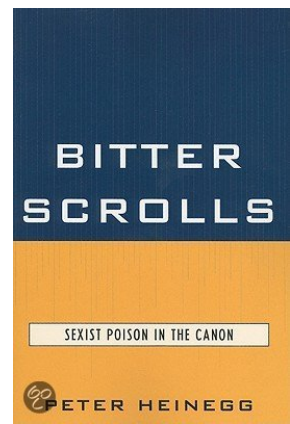

Bitter Scrolls is an ambitious book by Peter Heinegg. Beginning with the Epic of Gilgamesh, and romping through history to end up with John Donne and even PETER HEINEGE throwing in Marvin Gaye for good measure, Heinegg sets out to show the "toxicity of the texts" (I). He attempts to show how texts throughout history have spelled out "formulaic roles" and have "spelled catastrophe for women and misery for the most of the rest of the human race." These classic texts, which form the foundation of many "Bible and literature" classes, Heinegg says, are oppressive of women and promote "evil" (7).

Heinegg claims these heroic texts have been shielded from our critiques. Rather, we, as a society, express our indignation at this oppression by pouring our critiques on "blatant forms of oppression like female infanticide (now mechanically updated by ultra-sound), foot-binding, polygyny, clitoridectomy, purdah, niqab, and so on" (7). Heinegg seems to imply that our failure to critique these classic works for the misogynistic texts that they are has led to all the ills in society that have afflicted women.

Heinegg's book, he himself claims, is a rock-throwing contest, which he thinks some will consider blasphemous. But, he reminds us in his introduction, it was the child who first noticed that the emperor was not wearing any clothes. This seems to imply that Heinegg is setting himself forth as this holy child, who alone can see the truth, can see the texts in all their nakedness, and proclaim to the rest of us what we have failed to see.

Admittedly, Heinegg does an excellent job of exposing and revealing the texts in all of their nakedness. Heinegg begins with the epic of Gilgamesh, which he says is "off to a very bad start" (9). Within chapter I alone, Heinegg throws in Henry Kissinger, Plato, Don Quixote, Adam, Job, and even Shakespeare to come up with his conclusion that the entire canon has some very basic guidelines for how males should behave. "So the basic outline and ground rules for the canon have been laid out; but the pattern is nowhere more vividly or emphatically presented than by Gilgamesh." This basic story line is "if the heroes don't always destroy the women they love, they always leave them bereft" (I6). 
Chapter 2 leads us into a study of Achilles, which is more or less a rehashing of The Iliad. Chapter 3 brings a study of the great trilogy by Aeschylus, the Oresteia. This myth, Heinegg states, "celebrates the triumph of the patriarchy over the primordial Earth goddesses and women in general. It's a stunning imaginative act, a brilliant etiological fiction, and twisted propaganda" (29). Heinegg's retelling of the trilogy is clear and succinct and draws out the violent and "poisonous" aspects that make this a tale intent on subjugating women. "It was a great victory-for the victors—and the key to it was the annihilation of Clytemnestra. First, she had to be demonized, turned into a grotesque image of malice and lust; then denied the protected status of motherhood (because she wasn't Orestes' 'real mother' and, ultimately, wished him dead); next, executed by order of Apollo, and last of all rendered a non-person by the loss of her right to revenge" (37).

Heinegg then leads his reader through an analysis of misogynistic texts of the Bible beginning with Moses. The only commentary Heinegg has made on biblical texts so far has been one passing reference in chapter I to wisdom literature which he claims, "came to Israel from Egypt and Assyria, and frequently took a dark, pessimistic, death-centered (see Job, Ecclesiastes) view of the human condition, [and] is also often bitterly misogynistic" (I4). In chapter 4, Heinegg attempts to wrap up all of Moses' life including explaining the Decalogue in six pages and even throwing Jesus in for good measure. It is not so much the text that has poisoned ensuing generations; Heinegg is concerned with those who continue to interpret as if they are ventriloquists bequeathing impressive information on a new generation and, as Heinegg puts it, "just like the endless generations of unthinking bibliolaters after them." Heinegg suggests in respect of the Ten Commandments that "on that solid foundation a whole superstructure of oppressive laws confidently rises" (42). His argument is that these texts have served to distort, disfigure, and dumb down generations of Jews, Christians, and Muslims.

Chapter 5 is a quiet journey through Paul. Jesus, Heinegg claims, does not seem to say anything misogynistic, however, it is not Jesus's words that we need to be concerned about. Heinegg tells us Paul did not count women, only concerned himself with men, but that he did have some women friends (54). Chapter 6, "Muhammad Keeps the Ladies in Line," wraps up Islam by comparing it to the Arabian Nights. Chapter 7 skips through the Renaissance and Boccaccio; chapter 8, the seventeenth century and Rabelais. Chapter 9 makes quick work of Shakespeare, conveniently diving into Milton, Pope, Wordsworth, Tolstoy, Yeats, and Lawrence in subsequent chapters. 
It is not that Heinegg is wrong in his analysis of the texts. The texts do contain what he claims, but he presents this information as if it is brand new, as if he is that boy who is the first to notice the emperor is naked. This approach ignores the years of struggles that various writers have invested in exposing these texts previously, working carefully with the texts, and taking great pains to uncover what Heinegg seems to believe has been a secret. $\mathrm{He}$ does admit that others have gone before him to critiques the texts, particularly the Bible, but they have failed: "Alternatively (and this is the preferred liberal loophole) one can water down, explain away, or just pass over the troubling texts. In days of yore, allegorizing them offered an elegant solution; but in modern times that seems too whimsical and loopy" (57).

Heinegg doesn't end his critique with the canon but bursts into popular culture bemoaning the continued use of women as objects. And the culprit may be young girls' dolls and undergarments. "And it's not as if young American women have necessarily gotten the message of feminism either. Many of them read chick lit and watch chick flicks, even as their younger sisters rave for Hannah Montana, collect Bratz dolls, and wear thong or bikini underpants" (I 59). I suppose in this analysis the blame all does lay on the women. Women who Heinegg identifies as finding power and positions of note include Sarah Palin and Ann Coulter.

The answer, Heinegg says, for feminists is to understand, criticize, and transcend the canon, to create a new one. As readers and critics of the canon, we control it, or so says Heinegg. It is our job to detoxify it. I'm glad that Heinegg, a man to be sure, knows what job it is that women now need to do. And I'm glad he has all the answers, though in his book, he doesn't give us any clue as to what they are, except that young girls should stop wearing thong underwear and alluring clothing. We are left to think that throwing away the canon will be a good thing and simply rewriting all of history will achieve the desired effect, with Heinegg, of course, at the helm.

What is most disturbing about Heinegg's work is not only the centuries of literature that he flays about without any thought to historical context or mention of critics who have done similar work, it is the lack of acknowledgment for any study that has gone before. There are no references to other scholars, no footnotes or endnotes, and no indices. In fact, at one point Heinegg states, "Not to put too fine a point on it, a huge chunk of all this misery comes from reading a bad book and taking it much too seriously. The Qur'an wouldn't be so awful if only readers were allowed to study it critically and discuss it skeptically; but within the umma that's just not done" (64-65). 
Now what feminist scholar would not like to jump on the bandwagon and bash misogynistic readings of texts? Heinegg's book, however, does not achieve that. He accomplishes a quick look at a large canon addressed with inflammatory language (even types "YAWN" into his text to show his boredom with the Qur'ann) that suggests women need to remedy this solution. After reading Heinegg's book, I have decided I should throw away my thong underwear, turn off the radio any time Hannah Montana comes on, throw all my books away, forget studying any book in Heinegg's canon and await Heinegg's finest words of wisdom. Feminist scholars who have come before, who have spent their lives and risked their jobs, taken chances, and advanced the cause of feminist scholarship beware: this book is not for you. However, Heinegg succeeds in bringing to light in a very quick succinct fashion misogynistic texts that a beginning feminist scholar, unfamiliar with the texts, might find helpful. Heinegg is also very right; we have a long way to go.

Karen Langton

Brite Divinity School

Texas Christian University 